\title{
The meaningful intentional purpose of the individual speaker
}

\author{
Jesús Martínez del Castillo \\ Department of Philology, Faculty of Business Studies and Tourism, Universidad de Almería, Almería, Spain
}

Email address:

jesus.gerardo@ual.es, apofansis@msn.com

To cite this article:

Jesús Martínez del Castillo. The Meaningful Intentional Purpose of the Individual Speaker. International Journal of Language and Linguistics. Special Issue: Linguistics of Saying. Vol. 3, No. 6-1, 2015, pp. 5-10. doi: 10.11648/j.ijll.s.2015030601.12

\begin{abstract}
Linguistics of saying studies language in its birth. Language is the mental activity executed by speaking subjects. Linguistics of saying consists in analyzing speech acts as the result of an act of knowing. Speaking subjects speak because they have something to say; they say because they define themselves before the circumstance they are in; and this is possible because they are able to know. Speaking, then, is speaking, saying and knowing. In this sense there is a progressive determination. Knowing makes possible saying, and saying determines speaking, or, in other words: speaking involves saying and knowing, and saying involves knowing. The problem thus is to determine the linguistic intention of the individual speaker to say something in every speech act.
\end{abstract}

Keywords: The Human Subject, Speaking, Saying and Knowing, Thought, The Speech Act, The Act of Knowing

\section{Introduction}

Linguistics of saying starts with the human reality of language. Speakers live language thus making it real. Speakers intuit, create, acquire, perform, speak and say, use, evaluate and even speak of language. Since speakers intuit language, language is something thought by speakers as contents of their conscience, something coming from their interior. For a speaking subject, language manifests itself in $\delta i \alpha \lambda o \gamma o \varsigma$, that is, in the interchange of the speaker with the listener, as activity, the activity of speaking, and as a mode of that activity (speaking English, Spanish, French, etc). Since language manifests itself in $\delta \dot{\alpha} \lambda \mathrm{o} \gamma \mathrm{\gamma}, \mathrm{s}$, language is for others. Since language is created at the moment of speaking, it is speaking, saying and knowing in a particular language. Language, thus, is universal, historical and individual. Since creative speakers perform language, they at the same time acquire language. Language thus is creative, technical and individual knowledge. Since language is spoken, it is real.

Language thus for a human subject constitutes something at the same time coming from the inside, something the human subject lives, intuits and creates in his interior; and something coming to the speaker from the outside, something the speaker acquires, performs and uses in accordance with the conventions in the tradition of speaking in his speech community. On the other hand, language constitutes something existing in front of the speaker who uses it, that is, language manifests as an activity and a mode of that activity, that is, as speaking and as a language, as speaking a particular language. Because of this speakers are interested in what language, the activity of speaking and the mode of the activity of speaking are. That is, speakers, at the same time as they perform and use language, evaluate language and the performance of it.

From this multiple reality we can draw the most important conclusion: language is nothing but human subjects who speak, because they have something to say; they say because they are able to know, define themselves before the circumstance they are in. Because of this they compromise, thus constituting themselves in the guarantee of the states of affairs created. With this we have found the radical reality language stands on. Language is nothing existing in itself, nothing there, nothing objective. It has no concrete existence. It exists in the minds of speakers and is executed as something

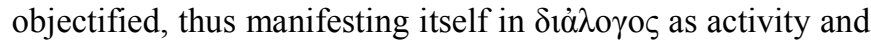
mode of that activity (=a particular language) in individual performances, that is, in the speech act.

In order to study language the first thing to bear in mind is the different aspects referred to above: some aspects of language come from the interior of the individual speaking subject, some come to the individual speaker from the outside, from the speech community, and some defy human subjects standing in front of them coming from "the other one" (the listener) as far as content is concerned, or from the context or 
the tradition in the technique of speaking. For language to be given the three different types of aspects stated here must be conjugated. Language exists because it is intuited, created and lived by speakers. Language is executed because it is acquired, performed and used by speakers. Language is something existing in front of us because it manifests itself when spoken in the speech act ( $\left.\delta \dot{\alpha} \lambda \lambda_{0} \gamma o \zeta\right)$ in different historical modes of the activity of speaking (languages). And finally, language is constantly being evaluated when it is being performed. To study language thus it is necessary to study language in its birth, that is, when language is intuited, created, and acquired by speakers and in speakers. Once language has been performed (in a particular language) it constitutes something standing in front of us. Since language is performed and exists as an individual execution, since individual subjects are free and historical having to do something with the circumstance they are in, language is nothing but the meaningful intentional purpose of the individual speaker to speak and say. Language thus is summarized in saying.

Linguistics of saying starts with saying or the definition of the human subject before the circumstance he is in at any moment, thus constituting himself in the guarantee of the implicit rearrangement of things (state of affairs) resulting in that definition. This means that the action of the human subject is nothing but compromise. When human subjects involved in a particular circumstance do something in order to survive they rearrange things trying to overcome the circumstance they are in. This arrangement involves saying something thus compromising.

Human subjects speak, say and know because they can apprehend things and interpret them. In this sense linguistics of saying is linguistics of speaking, saying and knowing. Since saying involves the rearrangement of things and the compromise of the speaking subject before the circumstance he is in, language must be explained in its birth in the interior of the cognizant ${ }^{1}$, saying and speaking subject. Language is born whenever it is spoken, and whenever it is spoken the cognizant, saying and speaking subject uses all types of means at his disposal. Even more: the cognizant, saying and speaking subject uses all his being and all things he is involved in in order to say something. Saying thus constitutes the determination and the purpose of language.

\section{Linguistics of Saying as a Theory of Knowledge}

Language thus is cognizant activity embracing,

- Knowing or the way the human subject approaches reality in order to apprehend and dominate it in the sense the most convenient to him in the circumstance he is in.

- Saying or the interior activity of the subject consisting in rearranging those things known by him thus constituting himself in the guarantee of that systematization made on

\footnotetext{
${ }^{1}$ I would say cognizant, cognizance rather than cognitive and cognition, since the latter involve a psychological component.
}

the things known, that is, compromising before and with them; and

- Speaking with the implicit search of traditional means of expression in order to say something of the things known. Language, thus, is the activity consisting in knowing, saying and speaking by a subject who is in a particular circumstance.

Considered in its deepest genesis knowing is first. Knowing makes possible for the subject to define himself before the things he knows thus constituting saying. Speaking, then, is the last, the expression of that thing before which the subject defines himself, something possible because the subject knows. Knowing, in principle, is wider than saying. Saying determines both knowing and speaking but in the opposite direction: knowing above and speaking below. Saying determines knowing above in the sense that it is the activity of a free subject, saying is the purpose of knowing; with this knowing goes as far as saying determines it to. Saying involves an act of contemplation of the things apprehended and known determining it. On the other hand, saying determines speaking below in the sense that speaking exists because it is the expression of saying.

Knowing starts with the apprehension of things in the world on the part of the human subject. The apprehension of things can be made in two ways, either through the senses or directly through intuition. Intuition is just like a sudden flash you have or have not. Intuition is the fact of having something present in its entire reality, that is, of having and contemplating the thing known just as it keeps necessary connections in the elements it is constituted in. The necessary connections in intuition are summarized in contemplating the thing known as necessary and universal. Intuition, the same as with the senses, is something sensitive but, different from the senses, it is pure creation. In both cases, either through the senses or in intuition, apprehension, as something given, is of sensitive character. It constitutes what Aristotle calls aisthesis, the "sensation" affecting me and only me in a particular sense and in a particular moment. Anything I can apprehend, either by my senses or pure creation in intuition, constitutes aísthesis, something of concrete and sensitive character. Knowing, thus, starts with something affecting me and only me. My knowledge so far, of concrete and sensitive character, is just like the knowledge of animals. What I can feel is something I live because my nature is sensitive, something I cannot share with anyone else. As an illustration of this type of concrete and sensitive knowledge take such human activities as driving a car, playing the piano, making those thousands of small pragmatic activities in our daily life (walking, putting on clothes, dressing up, tying shoelaces, etc.). It is a kind of knowledge not needing words. With this type of knowledge I cannot do anything but living it, executing it in a living way, enjoying it or suffering it, but I cannot manipulate it to my interest.

In order to make my knowledge properly human, that is, in order to transform my original impulse to know, aisthesis, into a type of knowledge determined by human freedom, it is necessary that the construct created so far in the very act of 
apprehending things through my senses or my intuition, be made into something non-concrete and non-sensitive, that is, be made into something abstract. In this way when the thing lived by me, which may be pleasant or constitute my displeasure, affecting me and only me, is made into something abstract I can manipulate it in a treble sense,

- I can use it to create my own conscience. The subject then realizes himself thus feeling separate from the thing perceived. This separating myself from the thing perceived by me, affecting me sensitively and nobody else, is an operation entirely mental and free. If, for example, I am cold I feel a sensation affecting me and only me in as much as it makes me feel unbalanced as to the temperature I need to live and continue living. Now then, if I say I am cold I contemplate that uncomfortable sensation as something different from me. The situation is the following: on the one hand it is that state of affairs I name "cold", and on the other it is me who suffers that state of affairs named "cold". As a consequence I contemplate that state of affairs named cold as something I can get rid of. I am different from that state affecting me and only me. I am suffering it and wish I were not cold.

- I can use it to keep it in my conscience. That sensation affecting me uncomfortably named "cold" by me as something different from me, if it is overcome in some way it will leave its print as something I have experienced, likely to be used in subsequent new situations. When I feel that sensation again, I shall probably recognize it as something already experienced, something I can immediately remember the way I overcame it and got rid of it. As a consequence I can use the same procedure in order to overcome this new situation, not feeling that unpleasant sensation. If, on the contrary, I had not named that sensation and had not stored it although it was only in my mind, it would constitute a new situation and then I would have to start anew.

- I can use it to offer it to the others thus trying to get them involved in some way or another in that sensation lived and known by me and only me. In this sense if I say I am cold I may expect the other subjects around me to help me get rid of that uncomfortable situation affecting me and only me. My listener may then act in some way desired by me.

Saying, as the definition of the subject before the situation created in his act of knowing, as a free act, determines and guides knowing, as we have said. In this sense there is no direct connection between the thing I know and the thing perceived by me through my senses or my aisthesis: it is a free connection created by me. The mere fact of saying I am cold, to follow with the example, means that I defined myself before that situation referred to.

Since that sensation is perceived by me and only me, my listener may not understand it thus saying just the contrary, it is not cold. Both statements may be true at the same time. Every speaker can consider the state of affairs in question affecting him in a different way thus defining himself before the same real state of affairs and constituting himself as the guarantee of the contents of their respective definition. Saying in this way is free, thus manifesting my freedom in knowing. If I previously said it is cold I made what I lived into words with abstract contents, a combination of sounds evoking and representing something real with abstract means of expression. My listener will take that evocation in my words and in a more complicated combination may think but it is not cold, I am not cold. At the same time, he may think, cold is something provoked in us from the outside, I accept he is cold and then define himself in the wrong way round, but it is not cold. With this my listener mentally lives a similar situation in his interior, thus provoking a new aisthesis in his interior and defining himself before the new situation and his aisthesis.

As a consequence, the universality to be found in the act of knowing $^{2}$ is knowing itself. Knowing is individual. It cannot be otherwise. Every cognizant, saying and speaking subject knows (universal aspect of knowing) individually (individual aspect). If at the same time we consider that we always know and at any moment, and that this time we know is by no means the first one we know, we can see in knowing historical facts and procedures. Acts of knowing once formulated and now in force in the tradition, acts we now use because we learnt them from the tradition, constitute formulas to know in force in our speech community. These types of formulas of knowledge sometimes, the great majority of times, constitute beliefs, traditional forms of knowing in accordance with we can see things in the world thus constituting, they all together, particular modes of thinking and different idiomatic contexts 3 .

All this constitutes a new component in the act of knowing, the meaningful intentional purpose of the individual speaker. Every speaker says what he wants to and what he can. They mean this or that, and since saying is first in the act of speaking, saying and knowing, the meaningful intentional purpose constitutes the motivation in accordance with the individual subject executes his freedom, that is, it constitutes the free motivation of knowing. Saying is specified in the meaningful intentional purpose of the individual speaker. The fact of speaking, saying and knowing performed by the subject, defining himself freely before the circumstance he is in and compromising, is specified in the meaningful intentional purpose of the individual subject, something always unpredictable, sporadic, contextual and momentary, determining the act of speaking, saying and knowing.

From this point of view language does not exist, it is the creation of meanings; a particular language does not have concrete existence either but virtual existence as the idiomatic knowledge of speakers, a technical knowledge proper of this or that speaker as a member of this or that particular speech community. The only thing with concrete existence, something to be verified in itself, is speech acts. These

\footnotetext{
${ }^{2}$ I would say knowing rather than knowledge because 'knowing', since it is expressed with a verb, is active and dynamic but 'knowledge', as it is expressed with a noun, is static.

${ }^{3}$ cf. Eugenio Coseriu, 1982, pp. 308-319.
} 
manifest the way of being of their creators, subjects who speak, say and know, that is, subjects who are free and creative, absolute and transcendent, because they create reality using the means at their disposal in the tradition in the technique of speaking and creating new means of expression if their meaningful intentional purpose requires it. In as much as these subjects have to use historical means at their disposal in the tradition, they are as well historical, that is to say, limited and contingent, cognizant, saying and speaking subjects thus making themselves in history in participation with others in $\delta i \alpha \hat{\lambda} \mathrm{o} \gamma \mathrm{os}$.

The problem thus in linguistics of saying is,

- To determine how the creation of meanings is given, that is to say, how language is born in every speech act, in every act of speaking, saying and knowing;

- To determine, once analyzed he creation of meanings, what aspects of it are pure creation and what aspects belong to a particular language. A particular language as the virtual knowledge of speakers, historical as it is, offers series of forms, contents, rules, procedures, techniques, attitudes and beliefs thus constituting the almost exclusive means the individual subject faces the world of things with. Moreover, beyond that knowledge, participated with the other members of the speech community, the subject is provided with freedom, that is, with creativity.

- To determine what the subject apprehends and what he transforms or selects of the thing apprehended constituting his aisthesis.

- To determine in what sense the knowing subject creates his meaningful intentional purpose guiding his perceiving and apprehending in a particular sense from this moment on, thus realizing some aspects, neglecting others and orientating his selection of means of expression. These means of expression may be rejected by the individual subject if they consider them insufficient, thus creating new ones on the base of the old ones.

\section{Linguistics of Saying as Hermeneutics of the Speech Act}

Anything in language has to do with the speech act. On the contrary, the speech act is the expression of language and the particular language. A speech act represents the concrete performance of idiomatic knowledge. Considered from the point of view of the genesis of language, the speech act represents the birth of language. Linguistics of saying is focused on the analysis of the speech act. Linguistics of saying is interpretation, that is, hermeneutics, "a systematic founded revelation of particular contents" 4 , or the science of interpretation with the purpose of "determining in which

\footnotetext{
${ }^{4}$ Coseriu, 2006, p. 57.
}

whole the part must be remitted" 5 . Since we deal with hermeneutics we have to analyze the speech act from all possible points of view, especially from the point of view of the meaningful intentional purpose of its author. In this way we shall be able to determine which are those intellective operations in terms of the conditioners of knowledge and expressions. The thing determining our analysis is anything having to do with knowledge from the moment when knowledge starts with the sensitive and concrete and ends in words and contents of a particular language, good in principle for any possible speech6 and sometimes insufficient. In this sense the original meaning of words may have a capital relevance. To this respect, Ortega y Gasset says,

[Words] have a privileged sense, the greatest or authentic one, namely, the one they had when they were created [...] every word originally is the verbal or linguistic reaction before a typical living situation (my translation) ${ }^{7}$.

The really important thing in language analysis, thus, is not expression in itself, but those conditioners having prompted the speaking subject to select some means of expression in particular and not others.

This perspective of looking for and restricting to the original sense of words by Ortega y Gasset, however, is a challenge to the distinction of the different levels of linguistic determination by Coseriu ${ }^{8}$. Determining what is the meaningful intentional purpose of the individual speaker, unique and sporadic, does not contradict the separation of the aspects belonging to language, the particular language or the individual speaker. The act of knowing is an absolute one, that is, it is creation. Creation in its proper terms is free, thus using anything already performed either by the individual speaker or by the community found in the tradition of speaking. In the tradition of speaking many ideas, thoughts and beliefs may be in force. The speaker can use any of these at any moment in his private and exclusive interest. The use of a traditional element in a speech act means reviving the original sense and the significance of that element in a new sense. In this way the determination of the original sense of words or expressions means the performance of that element in a new and creative sense. There is thus no possible contradiction in separating and using the different levels of linguistic determination.

Since linguistics of saying is the hermeneutics of the speech $a c t$, it is in direct connection with text linguistics or the hermeneutics of sense, a discipline proposed by Coseriu9. The differences between them are to be found in the object of study of both. Linguistics of saying consists in the analysis of speech acts considering language in its birth, thus starting with the act of knowing, an act not to be considered as something already made but as something being made at the moment of speaking.

\footnotetext{
${ }^{5}$ Ortega y Gasset, Obras Completas, IX, p. 36

${ }^{6}$ Cf. Coseriu 1987, p. 19.

${ }^{7}$ Ortega y Gasset, 2002, p. 24.

${ }^{8}$ Coseriu, 1992, pp. 74 and ff.

${ }^{9}$ Cf. Coseriu, 2007.
} 
The object of study of text linguistics, on the contrary, consists in the analysis of texts as something already made. Both the speech act, on the one hand, and the text, on the other, must be related to the other aspects they are connected with.

Linguistics of saying wants to explain those elements constituting saying in a linguistic expression. Saying is the determination of speaking. Speaking, that is, language, would not exist if the human subject did not have the necessity to say something, that is, if the human subject himself did not define before the things he perceives and apprehends ${ }^{10}$. Saying would not exist either-nor speaking and thus language-if the subject did not know. Said in other words: the speaking subject faces the things surrounding him rearranging them and defining himself before them thus making them into real and manifesting himself in them. Speaking, that is, language, exists because it is given, or rather, it is going to be given in saying in the speech act; saying is possible because the subject can know and because he himself defines before the circumstance thus making saying into real. The speech act in this way constitutes an act of affirmation of an individual subject in what he is and in what he freely wants to be. Saying makes language to exist thus determining the creation of the speech act.

In a speech act thus you can find a process of determination: knowing makes possible the definition of the subject before the circumstance he is in thus determining saying with it; saying determines speaking thus making the individual subject select the means of expression of a particular language in his private and exclusive interest. But at the same time saying is determined as well by speaking, since speaking is historical thus conditioning saying. Knowing is given and can be given independent from saying. And saying can be given independent from speaking but not the wrong way round. Saying as the definition of the subject before the circumstance he is in, is knowledge, cognizant activity executed by a free subject before what he is and what the very subject makes it to be.

We saw above that human knowledge proper, as far as it is determined by the human freedom, starts when aisthesis 11 is made into something abstract. This transformation, for the cognizant subject, involves the possibility of manipulating what he has created, thus adapting the things constituting his circumstance to the construct the subject creates. This is made by means of a set of mental operations called intellective operations. These are selection, the establishment of a designation (or delimitation), the creation of a class or essence, relation, giving the construct a name, determination

10 Ortega y Gasset says, "every act of saying is a living action of a man; thus [...] the ultimate real and proper thing is not the thing "said" or dictum [...] but the fact that someone says something thus acting, doing something and compromising", (my translation, Ortega y Gasset 1992a, 253). On the other hand, he says, "there would not be languages if Man was not constitutively the "Sayer", that is, the one having things to say; because of this, I demand a new basic discipline, basic of all others integrating linguistics, which I call the Theory of saying" (my, translation, Ortega y Gasset, 2001, p. 245).

${ }^{11}$ Cf. Martínez del Castillo, 2013, §§ 4.5.2. 4.5.6. and the expression of the construct created to others 12 . The last intellective operation represents what traditionally constituted the explanation of speaking, the activity of speaking or language. Linguistics of saying analyzes all intellective operations having existed since the speech act was created as an act of knowing.

The unique action of knowing, saying and speaking can be summarized as well in the following way: the knowing subject selects something out of his initial sensation or intuition; assigns it a designation; creates a class or essence or category based on the construct created; relates it; gives it a name; and determines it thus applying it to real things, and finally expresses it in words.

As can be seen, the intellective operations said above involve two processes, the process of abstraction (selection, the establishment of a designation or delimitation, the creation of a class or essence, and relation) followed by a process of fixing of the construct created - just the inverse process(giving the construct a name, determination and expression) thus executing of the speech act.

\section{Functions in Linguistics of Saying}

In linguistics of saying you can see two functions, given in all linguistic expressions but given differently in every case and in every language. These functions are the object of saying and the object of knowledge. In the act of knowing the creation of these two functions is executed by means of the different intellective operations constituting the speech act referred to above.

\subsection{The Object of Saying}

The object of saying is the aspect, underlined or not grammatically, because of which the expression is formulated. It constitutes the final purpose of the utterance. For example, when you say an expression such as,

My father has a Roll Royce

you can ask, what is the meaningful intentional purpose of this expression? Who is the author of it speaking of? Is he speaking of his father? Why is this expression said?

The author of this expression, given for granted it is real, is speaking of himself. He means how important or happy he feels since his father has a Roll Royce and probably his mates' fathers do not have a Roll Royce. The contents in the sentence are constituted in "my father" and "a Roll Royce" put together with the verbal synthesis of "have". But the speaker in question in order to orientate the message to him, uses the most unimportant grammatical element, the possessive determiner "my". "My" represents the message of the expression, that is, the "saying", the object constituting the reason why the expression is said.

\footnotetext{
${ }^{12}$ These intellective operations executed in the speech act will be explained in a separate article.
} 


\subsection{The Object of Knowledge}

The object of knowledge, on the contrary, is the means of expression used to create the object of saying. The means of expression for a human subject can be very varied, some may be linguistic and some non-linguistic thus accompanying or substituting for the linguistic expression. In the example given above, the object of knowledge is "a Roll Royce". The speaker tries to draw his listeners' attention on a particular high quality car belonging to him because it is his father's.

The object of knowledge as far as an act of knowing performed, constitutes the first foundation of the speech act. It involves re-structuring the things surrounding the speaking subject in a particular way. Thanks to this re-structuring or this creation of meanings, the speaking subject has something to say.

These functions can be found with the help of the different intellective operations given in the speech act. The speaking, saying and knowing subject, with the help of context and the knowledge of things, interprets the sense of words, adding mentally the deficiencies he finds in language.

\section{Conclusions}

In the act of knowing, a new component is to be born in mind: the meaningful intentional purpose of the individual speaker. Every speaker says what he can and wants to. They mean this or that, and since saying is first in the act of speaking, saying and knowing, the meaningful intentional purpose constitutes the motivation in accordance with the individual subject executes his freedom, that is, it constitutes the free motivation of knowing and thus speaking. Saying is specified in the meaningful intentional purpose of the individual speaker.

Since the meaningful intentional purpose of the individual speaker is free, the analysis of language cannot be but hermeneutics, both transcendental and empirical. As Humboldt would say, it is transcendental hermeneutics and empirical verification.

\section{References}

[1] Coseriu, E., Principios de semántica estructural, Madrid: Gredos, 1981 (1977).

[2] Coseriu, E., Teoría del lenguaje y lingüística general: cinco estudios, Madrid, Editorial Gredos, (1982) [1962].

[3] Coseriu, E., Gramática, semántica, universales. Estudios de gramática funcional, Madrid: Gredos, 1987 [1978].

[4] Coseriu, E., Competencia lingüística: elementos de la teoría del hablar, Madrid, Editorial Gredos, 1992 [1988].

[5] Coseriu, E. y Ó. Loureda: Lenguaje y discurso, Pamplona, Eunsa, 2006.

[6] Coseriu, E. Lingüística del texto. Introducción a la hermenéutica del sentido, Arco/Libros, 2007 [1973].
[7] Di Cesare, D., Wilhelm von Humboldt y el estudio filosófico de las lenguas, traducción de Ana Agud, Anthropos, 1999.

[8] Heidegger, Martin, El ser y el tiempo, RBA Editores, 2002 [1944].

[9] Humboldt, W., «Ueber die Verschiedenheit des menschlichen Sprachbaues und ihren Einfluss auf die geistige Entwickelung des Menschengesschlechts» trad. Ana Agud: Sobre la diversidad de la estructura del lenguaje humano y su influencia sobre el desarrollo espiritual de la humanidad, Madrid, Anthropos y Ministerio de Educación y Ciencia, (1990) [1836].

[10] Martínez del Castillo, Jesús, La intelección, el significado, los adjetivos, Universidad de Almería, 1999.

[11] Martínez del Castillo, Jesús, La lingüística del decir. El logos semántico y el logos apofántico, Granada: Granada Lingvistica,

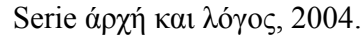

[12] Martínez del Castillo, Jesús, «Hablar, decir y conocer: el acto lingüístico», Oralia, 11 (2008): 375-97.

[13] Martínez del Castillo, Jesús: «El logos semántico y el logos apofántico» Enérgeia I, Online-Zeitschrift für Sprachwissenchaft, Sprachphilosophie und Sprachwissenschaftsgeschichte. 2009: 50-80.

[14] Martínez del Castillo, Jesús: Las relaciones lenguaje-pensamiento o el problema del logos. Madrid: Bilbioteca Nueva, 2010.

[15] Martínez del Castillo, Jesús, Sobre las categorias, Buenos Aires, Deauno.com, 2011.

[16] Martínez del Castillo, Jesús, ed. Eugenio Coseriu (1921-2002) en los comienzos del siglo XXI, 2 vols. in Analecta Malacitana, Anejos/86, 2012.

[17] Martínez del Castillo, Jesús: Psicología, lenguaje y libertad, in Analecta Malacitana, Anejos/89, Universidad de Málaga, 2012.

[18] Martínez del Castillo, Jesús: Modes of Thinking, Language and Linguistics, in Analecta Malacitana, Anejos/94, 2013, Universidad de Málaga.

[19] Ortega y Gasset, José, La idea de principio en Leibniz, Alianza Editorial, 1992a [1958].

[20] Ortega y Gasset, José, ¿Qué es conocimiento?, Alianza Editorial, 1992b [1984].

[21] José Ortega y Gasset, Sobre la razón histórica, Alianza Editorial, 1996 [1979].

[22] Ortega y Gasset, José, «El decir de la gente: la lengua. Hacia una nueva lingüística» in El hombre y la gente, Alianza Editorial, 2001 [1957].

[23] Ortega y Gasset, José, «El decir de la gente: las 'opiniones públicas', las 'vigencias sociales"'. El poder público» in El hombre y la gente, Alianza Editorial, 2001 [1957].

[24] Ortega y Gasset, José, "En torno al coloquio de Darmstadt", in Meditación de la técnica y otros ensayos de ciencia y filosofía, 2002 [1982]: 192-233.

[25] Ortega y Gasset, José, "Apuntes para un comentario al banquete de Platón", Obras completas, IX, Taurus, 2009: 729-758. 